\title{
Professional skill and understanding
}

\section{The Commercialisation of New Zealand Brian Easton, Auckland University Press. \\ Reviewed by Tony Simpson}

$\mathrm{I}^{\mathrm{N}}$ N THE EPONYMOUS ESSAY in his 1980 collection Writing By Candlelight ${ }^{1}$ the English historian Edward Thompson perceptively remarks that history may be located at the conjunction of lived and perceived experience. By history in this context he means not the academic study of past events but a tool for contemporary social analysis which places events both in a rational linear process, and in a broader context, over time. This can the be used to decode the meanings of present activities in the pubic sphere by reference to this process and context from the self conscious personal and experiential perspective of the reader or historian. It is pre-eminently a cultural approach to human affairs.

Economists, on the other hand, have a penchant for analysing the meanings of events within a given intellectual framework constructed from largely theoretical percepts which exist beyond time and history. Given the opportunity, they will dismantle and rebuild social structures not because they fail in practise but because they do not work in theory. If this seems familiar that is hardly surprising - such a process has been going on in New Zealand for over a decade. Dabblers in expertise, to borrow a phrase from Rex Fairburn have been once again licensed to experiment on the vile body of the state. $^{2}$

For most of that decade opponents of these political developments have struggled to find a basis for a critique. One of their best guides in this regard has been Brian Easton who combines professional skill as an economist with an understanding of the uses of historical process in explicating what events signify. In his most recent book, The Commercialisation of New Zealand ${ }^{3}$ he amply illustrates the value of this approach. This is in itself an act of courage. As he himself notes, economists who have opposed the neo-classical orthodoxies of the recent past in New Zealand have often found themselves derided or worse. This notwithstanding, Easton cautions us not to dismiss economics as a tool of analysis and an aid to understanding. But he also quotes approvingly from a past teacher who remarked that while economics was good at raising questions it did less well when it comes to answering them. And he warns of the problems which immediately arise if the analysis confines itself to economics alone and ignores the other social sciences. In a passage which appealed to me particularly he cites George Akerlof as writing:

... economic theorists, like French chefs in regard to food, have developed stylised models whose ingredients are limited by some unwritten rules. Just as traditional French cooking does not use seaweed or raw fish, so neoclassical models do not make assumptions derived from psychology, anthropology or sociology. ${ }^{4}$

Nor poetry, nor history, nor literature either, he might have added (and does), and approvingly quotes Orwell's sardonic comment that the rulers not only write history but rewrite it as necessary. This might easily be a reference to the recent short television series Revolution ${ }^{5}$ which purported to describe New Zealand prior to 1984 (an interesting date for Orwellians), which described a country unrecognisable as the reality to those who had lived in it during that time. The series might, indeed, have been more aptly entitled Someone Else's Country had that title not already been taken. ${ }^{6}$ "New Zealand's philosopher kings," writes Easton equally sardonically, "have gone a step further, not so much ignoring history, as using it selectively to hide their mistakes. They are always promising a glorious future, never recalling their shabby past. Historians, more than anyone else, can remind us that the emperor is wearing no clothes."7

Easton's great strength in his critiques of the direction of public policy over the last decade is to understand that what we are dealing with here is not an economy but a culture and that the former may or may not be the expression of the latter. That it has not been so for the last 12 years is the key to unlocking all of the political events which have transpired since the Lange government came to power. But he also understands that the failure to make that connection and thereby to obscure the divergence between culture and economy has allowed the proponents of deregulation to indulge in a solipsistic conflation between economic liberalism and democratic accountability.

Following overseas ideological justification, those driving the New Zealand reforms have consistently argued that structural adjustment of the economy will deliver the social outcomes that the people of New Zealand demand of their community when it acts politically. This is what has lain behind, for instance, the wholesale rebuilding of New Zealand public sector structures so that they approximate what the architects of this change believe, with little justification, is a market place. What they have failed to grasp is that the marketplace is not a unique locus of culture in which goods and services are exchanged. It is, on the contrary, essentially indistinguishable from any other human group situation in that what is being exchanged are relative powers. The goods and services are merely the counters with which this exchange is conducted in 
these particular circumstances. Human beings are first and foremost citizens and not consumers. What the New Zealand reformers have done is not restructure the economy but commercialise the culture.

By missing the key nature of this as an aid to understanding recent events of which they have been partially the authors, the same reformers have failed to appreciate that far from delivering the outcomes New Zealanders want, they have ensured that these have progressively receded from our grasp. It is now much more difficult to deliver the social equity and egalitarianism which lie at the root of New Zealand identity than has been historically the case, because the structures erected over a period of more than a century to

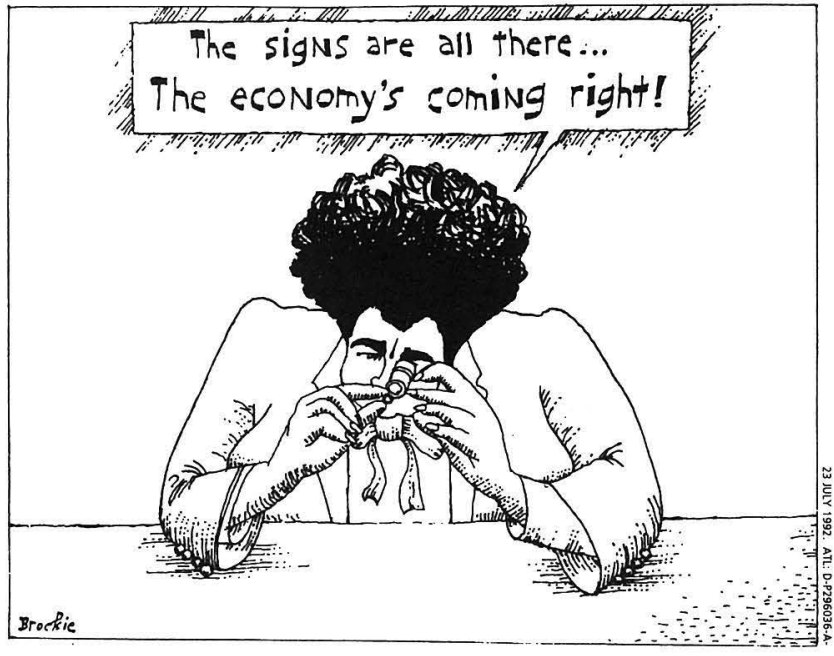
ensure that the rela-

tionships of power which characterised the metropolitan society from which most 19th-century New Zealand immigrants came and which they were determined not to replicate here, have been dismantled. There is much entertainment to be had from going back and reading the justifications advanced in such publications as Government Management ${ }^{8}$ for the changes made which claim that equity will be the outcome of deregulation. This has patently not been the case, but rather the contrary. There is less amusement involved in living these outcomes as an unemployed person, someone displaced by the process of change in the public sector, or as a semiskilled process worker daily suffering workplace exploitation because of the re-regulation of the labour market in favour of employers.

On the basis of his sharp observations Easton walks us through most of the areas in which the commercialisations of the last four governments have occurred - the health reforms, the labour market, education both core and tertiary, local and central government - and by recourse to the plain facts is able to paint a dismal but entirely sustainable picture of almost complete failure. This is particularly dramatised in a section on television broadcasting in which he is kind enough to quote from a cross examination by my- self of a Treasury witness to a Royal Commission in 1986. The promise of diversity and cultural choice so eloquently advocated by this witness as the consequence of a market driven approach to the management of television programming has, in the event, evolved into one of the most commercialised television systems in the world, and one which delivers little which expresses New Zealand but instead a programming mix of mind-numbing and alien monotony.

It is our tragedy, Easton concludes, that those who are responsible for these failures have also dismantled many of the social democratic structures which would have confronted them with their own folly and held them to account: Some of the worst crimes against humanity in the 20th century arose because those making policy were able to distance themselves from those on whom the policy impacted. This is not to say that the commercialisation of New Zealand should be equated with the worst horrors of the 20th century. But the parallel is the reducing of those who would suffer into abstractions whose humanness can be ignored in the interest of the grand, but inhuman, theory.

Our saving grace is that the game is not yet over, and Easton commends to our attention the Maori answer to the question of what is important: he tangata, he tangata, he tangata.

\section{NOTES}

1 E P Thompson Writing By Candlelight (London 1980)

2 A R D Fairburn "Dominion" in Collected Poems (Chch 1967)

3 Brian Easton The Commercialisation of New Zealand (AUP 1984)

4 G Akerlof An Economic Theorist's Book of Tales (Cambridge University Press 1984) cited by Easton op cit p253

5 A series of four programmes heavily weighted to approval of what have come to be known as neo-Right agendas and shown by Television One shortly before the 1996 election

6 Someone Else's Country is another television film which TVNZ has steadfastly declined to show, and which presents a very different perspective of events both pre- and post-1984.

7 Easton p 254

8 The Treasury Government Management Briefing to the incoming government 1987. 